\title{
molecules
}

ISSN 1420-3049

(C) 2007 by MDPI

www.mdpi.org/molecules

Full Paper

\section{Synthesis and Cytotoxic Activity of Some 3-Benzyl-5-Arylidenefuran-2(5H)-ones}

\section{Róbson Ricardo Teixeira ${ }^{1,2}$, Luiz Cláudio Almeida Barbosa ${ }^{1, *}$, Célia Regina Alvares Maltha ${ }^{1}$, Marcelo Eça Rocha ${ }^{1}$, Daniel Pereira Bezerra ${ }^{3}$, Letícia Veras Costa-Lotufo ${ }^{3}$, Cláudia Pessoa ${ }^{3}$ and Manoel Odorico Moraes ${ }^{3}$}

1 Department of Chemistry, Federal University of Viçosa, Av. P.H. Rolfs, S/N, CEP 36570-000, Viçosa, MG, Brazil

2 Department of Chemistry, Federal University of Minas Gerais, Av. Antônio Carlos, 6627, CEP 31270-901, Belo Horizonte, MG, Brazil

3 Department of Physiology and Pharmacology, Federal University of Ceará, Rua Coronel Nunes de Melo, 1127, CEP 60431-970, Fortaleza, CE, Brazil

* Author to whom correspondence should be addressed; E-mail: lcab@ufv.br; Tel.: (+55) 313899 3068; Fax: (+55) 3138993065

Received: 26 April 2007; in revised form: 21 May 2007 / Accepted: 21 May 2007 / Published: 24 May 2007

\begin{abstract}
Benzyl-furan-2(5H)-one (2a) and 3-(4-bromobenzyl)-furan-2(5H)-one (2b) were treated with TBDMSOTf and converted into the corresponding tert-butyldimethylsilylfuran ethers. These furans were further condensed with several aromatic aldehydes affording compounds 5-14 with general 3-benzyl-5-arylidene-furan-2(5H)-one structures in $31 \%$ to $98 \%$ yields. Such compounds are analogues of the naturally occurring nostoclide lactones, reported to present moderate cytotoxic activity. Compounds 5-14 were submitted to an in vitro bioassay against the HL-60, HCT-8, SF295 and MDA-MB-435 cancer cell lines using the MTT cytotoxicity assay.
\end{abstract}

Keywords: Nostoclides, cytotoxic activity, lactones, $\gamma$-alkylidenebutenolides. 


\section{Introduction}

$\alpha, \beta$-Unsaturated lactones possessing an alkylidene appendage group at the $\gamma$-position, are frequently termed $\gamma$-alkylidenebutenolides [1-3]. Over the past few decades, an increasing number of these compounds has been isolated from various natural sources [4]. The members of this class of compounds vary greatly in structural complexity, as well as functionality. Besides that, many of them have been shown to display a wide range of biological activities, such as the antibiotic activity displayed by protoanemonin [5-7], the cytotoxicity associated with the goniobutenolides A and B [812], and the inhibition of cholesterol biosynthesis observed with xerulin and xerulinic acid [13-14]. Two other interesting examples of $\gamma$-alkylidenebutenolides are the compounds 3-methyl-2H-furo[2,3c]pyran-2-one and peridinin. The former is known to activate seed germination [15] while the latter corresponds to one of the most complex $\gamma$-alkylidenebutenolides known to date [16]. Peridinin plays an important role in the photosynthesis of sea plankton (Figure 1).

Figure 1. Some examples of $\gamma$-alkylidenobutenolides.<smiles>C=C1C=CC(=O)O1</smiles>

Protoanemonin<smiles>O=C1C=CC(=C[C@@H](O)[C@H](O)c2ccccc2)O1</smiles>

Goniobutenolide A<smiles>O=C1CC/C(=C\[C@@H](O)[C@H](O)c2ccccc2)O1</smiles>

Goniobutenolide B

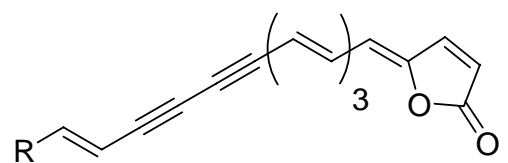

Xerulin $\left(\mathrm{R}=\mathrm{CH}_{3}\right)$ Xerulinic Acid $(\mathrm{R}=\mathrm{COOH})$<smiles>CC(=O)O[C@H]1CC(C)(C)C(=C=CC(C)=CC=CC=CC=C(C)C=C2C=C(C=C[C@]3(O)C(C)(C)C[C@H](O)CC3(C)C)C(=O)O2)[C@@](C)(O)C1</smiles>

Peridinin<smiles>Cc1c2ccocc-2oc1=O</smiles>

3-methyl-2H-furo[2,3-c]pyran-2-one

In 1993, Yang and co-workers reported the isolation of two-chlorinated metabolites, named nostoclides I and II (Figure 2), from the culture of a symbiotic blue-green alga, Nostoc sp., in Peltigera canina, a common lichen [17]. Since their discovery, these $\gamma$-alkydenebutenolides have attracted the attention of synthetic organic chemists, which has resulted in the development of different approaches to achieve the total synthesis of these secondary metabolites [18-20]. 
Figure 2. Structure of the nostoclides ( $\mathrm{R}=\mathrm{Cl}$, nostoclide $\mathrm{I} ; \mathrm{R}=\mathrm{H}$, nostoclide II).

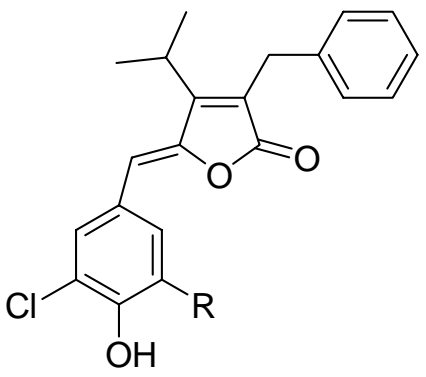

1

Although the nostoclides have been known since 1993, their biological properties have not been fully investigated. It has been suggested that these compounds may be alleopathic agents, since it was observed that the lichen Peltigera canina is able to support an unusually clean, contamination-free culture. Besides that, both compounds showed moderate cytoxicity against the cell lines Neuro-2a CCL 131 and KB CCL 17 [17].

As part of our ongoing efforts to develop bioactive compounds [21-25], and taking into consideration that there is no systematic investigation regarding the cytotoxic activity of nostoclides analogues, we describe herein the preparation and evaluation of antitumour activity of ten new lactone analogues of the nostoclides.

\section{Results and Discussion}

\section{Preparation of lactones}

The vinologous aldol reaction with the silyloxy diene furan synthon and the relevant aldehydes was the strategy utilized to prepare compounds 5-14 [18,20, 26-29]. Thus, treatment of lactones 2a or 2b with tert-butyldimethylsilyltrifluoromethanesulfonate (TBDMSOTf) and diisopropylethylamine (DIPEA) resulted in the formation of the furan 3, which was not isolated. This compound, in turn, reacted with suitable aldehydes to give the adducts presenting the general structure 4 . The addition of DBU to 4 under refluxing conditions led to an elimination process with concomitant formation of the nostoclide lactone analogues $\mathbf{5 - 1 4}$ in yields ranging from 31\% to 98\% (Scheme 1). It is important to note that in the case of compounds 12-14, the removal of the tert-butyldimethylsilyl (TBDMS) protecting group was accomplished by utilizing a 1:1 mixture of MeCN/HF [30].

Although reaction conditions were not optimized, in general the reactions were complete within three hours after the addition of DBU under refluxing conditions. For the production of the 3nitrobenzylidene derivative, the reaction mixture was refluxed for 1 hour, a procedure that afforded compound 11 in moderate yield (31\%). It was observed that extended refluxing times led to the formation of a complex mixture. For not well understood reasons, a moderate yield was also obtained for compound $\mathbf{6}$. The synthetic route described above allowed the synthesis of a variety of compounds presenting different substitution patterns with respect to the arylidene moiety (Scheme 1). 
The lactones 5-14 were fully characterized based on NMR, IR spectroscopic and MS spectrometric data. In all cases, the presence of molecular ion peaks was observed in the mass spectra, which correlated with the corresponding molecular formulas of the compounds.

Scheme 1. Synthetic route involved in the preparation of lactones 5-14.

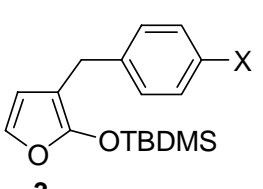

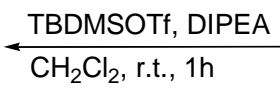

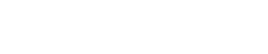

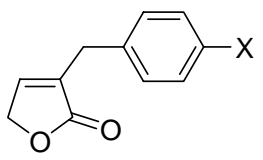

2a: $X=H$

$2 b: X=B r$<smiles>[R]c1ccc(C)c(C)c1</smiles>

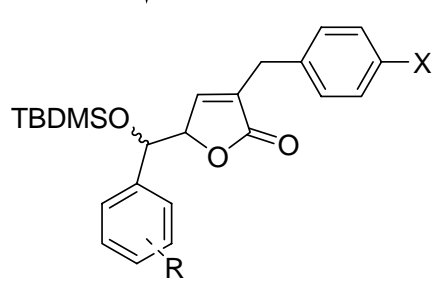

4

$\mathrm{DBU}, \mathrm{CH}_{2} \mathrm{Cl}_{2}$, reflux, 3h
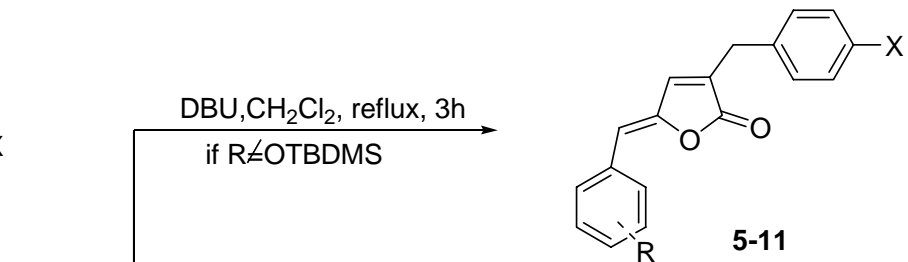

1) $\mathrm{DBU}, \mathrm{CH}_{2} \mathrm{Cl}_{2}$, reflux, $3 \mathrm{~h}$

2) $\mathrm{MeCN} / \mathrm{HF}(1: 1)$, r.t., $3 \mathrm{~h}$ if $\mathrm{R}=\mathrm{OTBDMS}$

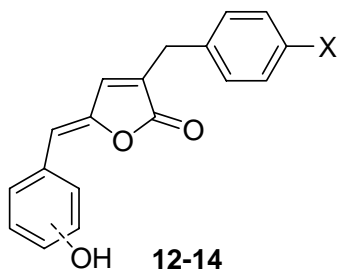

\begin{tabular}{lllll}
\hline Compound & Arylidene Group & $\mathrm{X}$ & $v_{\mathrm{CO}}\left(\mathrm{cm}^{-1}\right)$ & Yield* $\left.^{*} \%\right)$ \\
\hline $\mathbf{5}$ & 1,3-dioxalanebenzylidene & $\mathrm{H}$ & 1736 & $86(Z)$ \\
$\mathbf{6}$ & 1,3-dioxalanebenzylidene & $\mathrm{Br}$ & 1729 & $40(Z)$ \\
$\mathbf{7}$ & 2,4,6-trimethoxybenzylidene & $\mathrm{H}$ & 1747 & $83(E)$ \\
$\mathbf{8}$ & 4-bromobenzylidene & $\mathrm{H}$ & 1763 & $75(Z)$ \\
$\mathbf{9}$ & benzylidene & $\mathrm{Br}$ & 1764 & $98(Z)$ \\
$\mathbf{1 0}$ & 3-methylbenzylidene & $\mathrm{Br}$ & 1747 & $59(Z)$ \\
$\mathbf{1 1}$ & 3-nitrobenzylidene & $\mathrm{Br}$ & 1754 & $31(Z)$ \\
$\mathbf{1 2}$ & 4-hydroxybenzylidene & $\mathrm{H}$ & 1731 & $91(Z)$ \\
$\mathbf{1 3}$ & 3-hydroxybenzylidene & $\mathrm{H}$ & 1737 & $78(Z)$ \\
$\mathbf{1 4}$ & 2-hydroxybenzylidene & $\mathrm{H}$ & 1721 & $74(Z)$ \\
\hline
\end{tabular}

*Yields based on compounds $\mathbf{2} \mathbf{a}$ and $\mathbf{2 b}$

The IR spectra of these compounds revealed intense absorption bands ranging from 1721-1764 $\mathrm{cm}^{-1}$ assigned to carbonyl groups. The frequency of these absorptions varies according to the substitution pattern on the arylidene ring. As expected, a decrease in the carbonyl absorption frequencies was observed for compounds having electron-donating groups such as $\mathrm{OH}, \mathrm{OCH}_{3}$ and methylenedioxy attached to the benzylidene ring (Scheme 1).

A combination of two dimensional NMR analyses (HSQC and HMBC) of the lactones synthesized not only confirmed the presence of a five membered $\alpha, \beta$-unsaturated lactone ring moiety, substituted by both the benzyl and benzylidene functionalities, but also allowed complete hydrogen and carbon assignments. Taking compound $\mathbf{1 0}$ into consideration, some of the major long-range correlations $\left(J^{2}\right.$ and $J^{3}$ ) observed in the HMBC contour plot are depicted in Scheme 2. 
Scheme 2. Some long range correlations found in the HMBC contour plot of compound $\mathbf{1 0 .}$

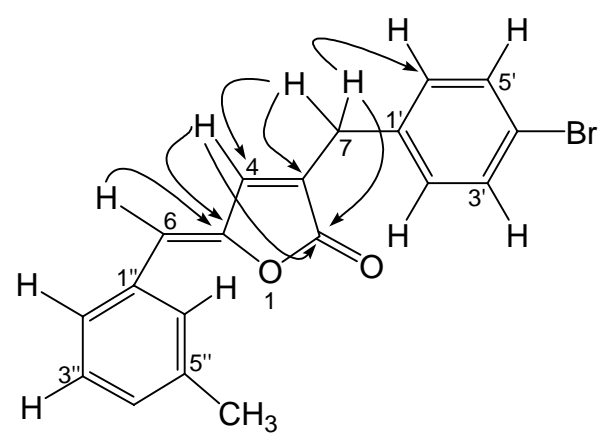

The stereochemistry of the exocyclic double bound in lactones 5-14 was confirmed by 2-D NOESY experiments. With the exception of compound 7, all lactones synthesized exhibited the $(Z)$ configuration (Scheme 1). This configuration assignment was supported by the observation of a NOE cross-peak between $\mathrm{H}-4$ and $\mathrm{H}-6$, as exemplified in Scheme 3 for compound 10, where other correlations observed in the NOESY contour plot are also shown.

Scheme 3. Correlations observed in the NOESY contour plot of compound $\mathbf{1 0 .}$

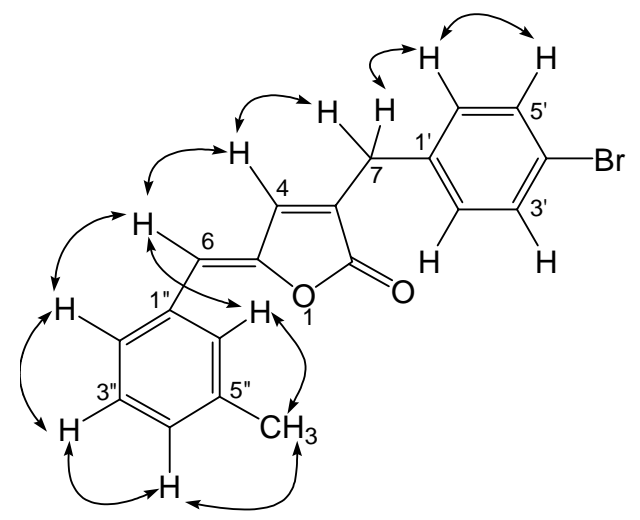

One interesting aspect found in the NOESY contour plot of compound $\mathbf{1 4}$ deserves comment. The expected NOE cross-peak between H-2" and H-6 was not observed. This fact was interpreted in terms of a preferential conformation attained by the compound. In order to alleviate the non-bonding steric repulsion between the O-1 electronic pairs and the $\mathrm{OH}$ group (conformation A), compound 14 preferentially attains conformation B (Scheme 4).

Scheme 4. Conformations of compound 14.

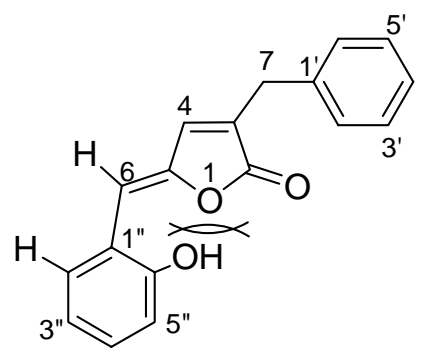<smiles>[2H]c1cccc(O)c1C=C1C=C([CH]c2ccccc2)C(=O)O1</smiles> 
In this conformation, the distance between the aforementioned hydrogens is longer when compared with conformation A. Thus, the cross-peak between H-2" and H-6 is not observed. To support this proposal, semi-empirical calculations, using the AM1 algorithm [31], were performed to evaluate the difference in energy between the two conformations and also to get insight about the distances between the hydrogen atoms $\mathrm{H}-2$ " and $\mathrm{H}-6$ in the different conformations. The calculations revealed that conformation $\mathrm{A}$ is $5.81 \mathrm{kcal} \mathrm{mol}^{-1}$ higher in energy than conformation $\mathrm{B}$. Moreover, in conformation A the distance between H-2" and H-6 is $2.23 \AA$, while in conformation B the spatial separation between the hydrogen atoms is more pronounced and equal to $3.84 \AA$ (Scheme 5).

Scheme 5. Conformations $A$ and $B$ for lactone 14 and the corresponding heats of formation $\left(\Delta H_{\mathrm{f}}{ }^{\circ}\right)$ obtained from AM1 semi-empirical calculations. Distances (in $\AA$ ) between H2" and H-6 in the conformations are also shown. Oxygen, hydrogen and carbon atoms are, respectively, red, white and gray.

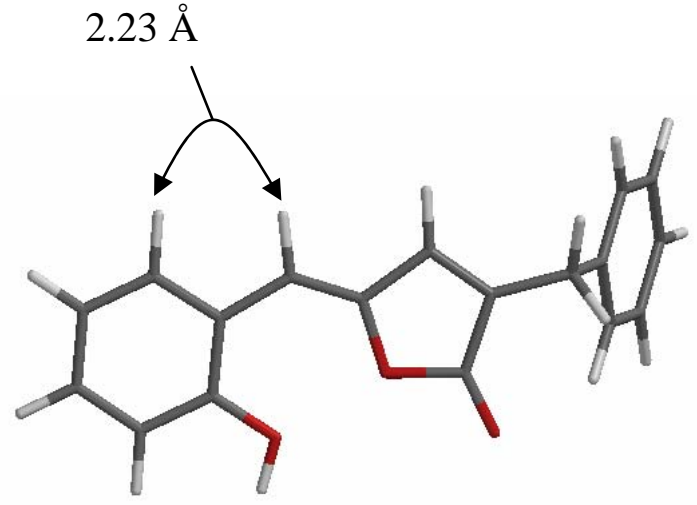

Conformation A: $\Delta H_{\mathrm{f}}^{\mathrm{o}}=-21.76 \mathrm{kcal} \mathrm{mol}^{-1}$

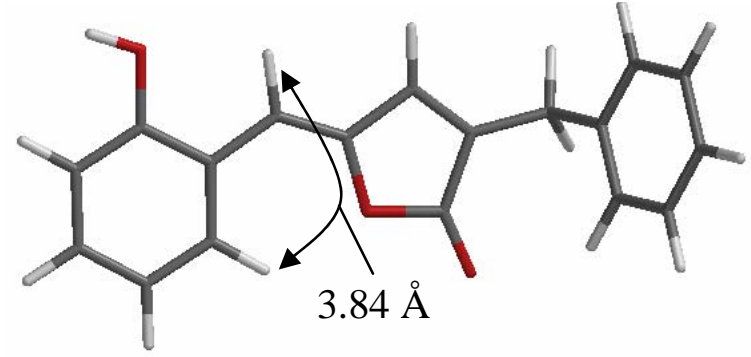

Conformation B: $\Delta H_{\mathrm{f}}^{\mathrm{o}}=-27.57 \mathrm{kcal} \mathrm{mol}^{-1}$

With regards to compound 7, the exocyclic double bond presented an $E$ configuration. Since the ortho positions are both substituted by methoxy groups, the compound attains the $E$ configuration to alleviate the non-bonding destabilizing steric interaction between $\mathrm{O}-1$ in the lactone ring and the methoxy groups. In fact, density functional theory calculations (B3LYP/6-31+G* level) using the Gaussian 03 program demonstrated that the $E$ configuration of substance $\mathbf{7}$ is more stable than the corresponding Z one [32].

The opposite situation was observed for the other nostoclide analogues synthesized. In this case, AM1 calculations revealed that the $Z$ isomer is more stable than the $E$ isomer, as exemplified in Scheme 6 , which shows the values of heat of formation $\left(\Delta H_{\mathrm{f}}{ }^{\circ}\right)$ found for different stereoisomers of compounds 8 and 14. The most stable conformation of each stereoisomer is depicted.

Thus, the reactions involved in the preparation of the nostoclide analogues probably predispose formation of the stereoisomers depicted in Scheme 1 and the isomer selection forces appear to be thermodynamic rather than kinetic in origin [32]. 
Scheme 6. Structures of the $\mathrm{Z}$ and $E$ minimum energy conformers for compounds $\mathbf{8}$ and 14. Oxygen, hydrogen, bromine, and carbon atoms are, respectively, red, white, orange and gray.

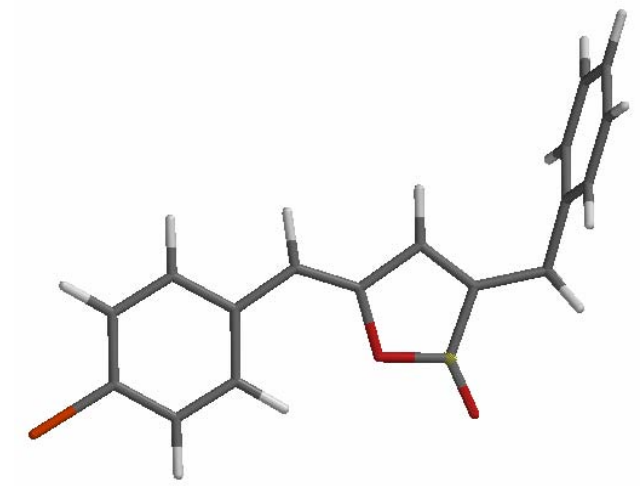

8(Z): $\Delta H_{\mathrm{f}}^{\mathrm{o}}=21.50 \mathrm{kcal} \mathrm{mol}^{-1}$

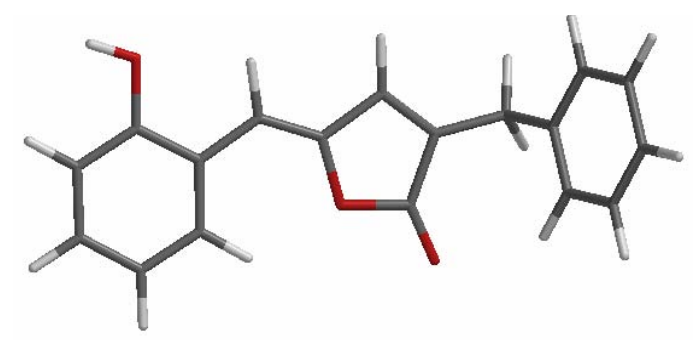

14(Z): $\Delta H_{\mathrm{f}}^{\mathrm{o}}=-27.57 \mathrm{kcal} \mathrm{mol}^{-1}$

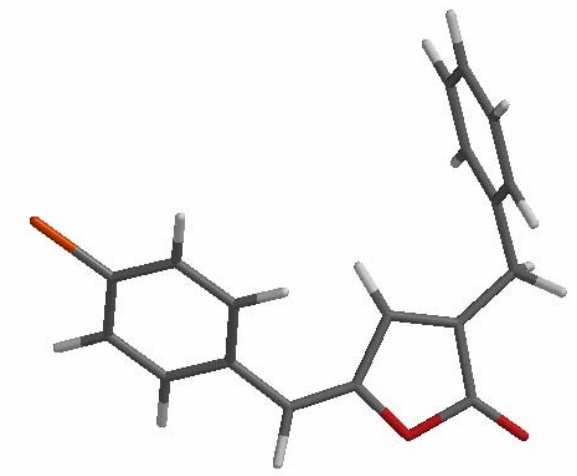

8(E): $\Delta H_{\mathrm{f}}^{\mathrm{o}}=22.20 \mathrm{kcal} \mathrm{mol}^{-1}$

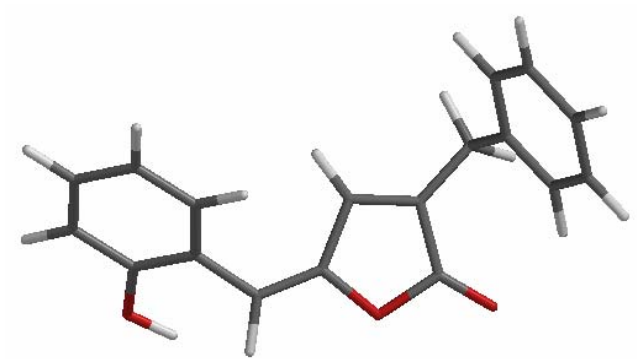

14(E): $\Delta H_{\mathrm{f}}^{\mathrm{o}}=-26.50 \mathrm{kcal} \mathrm{mol}^{-1}$

\section{Biological Evaluation}

The screening program of the U.S. National Cancer Institute (NCI), which tests more than 10,000 samples per year [33], uses cytotoxic analyses by the MTT method. It is a fast, sensitive and cheap methodology, described for the first time by Mosman [34] in 1983 and subsequently modified in 1996 by Alley et al. [35]. This evaluation allows one to easily determine the cytotoxicity of a particular compound, but it does not provide any insight into the mechanism of action [36].

In order to carry out a preliminary structure-activity relationship study, ten lactones 5-14 were prepared containing a variation on the substituting groups on both aromatic rings. Compounds 5, 7, 8, 12, 13 and 14 have a benzyl group linked at carbon 3 of the lactone ring, while compounds 6, 9, 10 and 11 have a 4-bromobenzyl group at the same position. We have chosen the bromine group arbitrarily, as we did for the groups present on the benzylidene ring, once we had no indication of the influence of such groups on the biological activity. The effects of lactones 5-14 were then evaluated against four tumour cell lines (HL-60, HCT-8, MDA/MB-435 and SF295), using the MTT assay. The results of the $\mathrm{IC}_{50}$ data $(\mu \mathrm{M})$ for the antitumour activities are presented in Table 1, along with the data obtained for doxorubicin, used as a positive control.

Compound 5 caused no effect on cell lines HL-60, MDA/MB-435 and SF295, but for the cell line HCT-8 a modest inhibition was observed $\left(\mathrm{IC}_{50}=101.5 \mu \mathrm{M}\right)$. A modest activity was also observed for compound 7 regarding MDA-MB-435 line cells $\left(\mathrm{IC}_{50}=119.5 \mu \mathrm{M}\right)$. The data obtained for compound $\mathbf{6}$, an analogue of compound 5 containing a bromine atom at carbon 4' of the benzyl ring, revealed no 
effect in any of the four cell lines tested, suggesting that the bromine had a negative influence on the bioactivity. The same negative results were observed for compound 11. The other two compounds (9 and 10) with a bromine atom on the benzyl ring had no activity against line cells HL-60 and SF295. Compounds 9 and 10 had small effects on cell lines HCT-8 $\left(\mathrm{IC}_{50}=114.4 \mu \mathrm{M}\right)$ and MDA/MB-435 $\left(\mathrm{IC}_{50}=82.8 \mu \mathrm{M}\right)$, respectively. All other compounds having the benzyl group at carbon 3 of the lactone ring showed moderate activity against at least one line cell tested. Compound 13, having an $\mathrm{OH}$ group at meta position in the benzylidene ring caused inhibition on all four line cells $\left(\mathrm{IC}_{50}=17.6\right.$ to $62.2 \mu \mathrm{M}$ ). The most potent proliferation inhibitors in this series was compound $\mathbf{1 4}$ with $\mathrm{IC}_{50}=8.9$ $\mu \mathrm{M}$ for HL-60 line cell. This compound caused no effect on the other cell lines. It is important to be pointed out that for the best of our knowledge it is the first time that nostoclides analogues are screened with respect to their cytotoxic activity.

Table 1 - Cytotoxic activity of compounds 5-14 on human tumour cell lines. Doxorubicin was used as positive control.

\begin{tabular}{|c|c|c|c|c|}
\hline \multirow[t]{2}{*}{ Comp. $\mathbf{n}^{0}$} & \multicolumn{4}{|c|}{$\begin{array}{c}\text { Cells }^{\mathrm{a}} \\
\mathrm{IC}_{50}^{\mathrm{b}}(\mu \mathrm{M} ; \text { confident interval })\end{array}$} \\
\hline & HL-60 & HCT-8 & MDA-MB-435 & SF295 \\
\hline 5 & $>130$ & 101.5(95.0-129.6) & $>130$ & $>130$ \\
\hline 6 & $>130$ & $>130$ & $>130$ & $>130$ \\
\hline 7 & $>130$ & $>130$ & 119.5(101.3-127.1) & $>130$ \\
\hline 8 & $>130$ & 52.8(32.2-80.3) & $>130$ & 110.2(90.9-128.1) \\
\hline 9 & $>130$ & 114.4(95.7-128.1) & $>130$ & $>130$ \\
\hline 10 & $>130$ & $>130$ & 82.8(60.1-90.8) & $>130$ \\
\hline 11 & $>130$ & $>130$ & $>130$ & $>130$ \\
\hline 12 & 108.9(88.3-121.4) & $>130$ & $62.2(44.8-78.0)$ & $>130$ \\
\hline 13 & 62.2(48.9-79.8) & $34.9(28.4-42.8)$ & 20.5(12.2-31.6) & 17.6(12.6-25.9) \\
\hline 14 & $8.9(5.4-15.8)$ & $>130$ & $>130$ & $>130$ \\
\hline Doxorubicin & $0.04(0.03-0.05)$ & $0.02(0.02-0.03)$ & $0.96(0.68-1.32)$ & $0.48(0.34-0.72)$ \\
\hline \multicolumn{5}{|c|}{$\begin{array}{l}\text { a Cells were plated in 96-well plates incubated under a } 5 \% \mathrm{CO}_{2} \text { atmosphere, at } 37{ }^{\circ} \mathrm{C} \text {, for } 72 \mathrm{~h} \text {, in } \\
\text { presence of concentrations of pure compounds ( } 0.39-25 \mu \mathrm{g} / \mathrm{mL} \text { ). Each concentration was tested in } \\
\text { triplicate and the analyses were performed in duplicate. }{ }^{\mathrm{b}} \text { Data are presented as } \mathrm{IC}_{50}(\mu \mathrm{M}) \text { values } \\
\text { and } 95 \% \text { confidence interval (given in parentheses) obtained from at least three independent } \\
\text { experiments. }\end{array}$} \\
\hline
\end{tabular}

\section{Conclusions}

In summary, we have demonstrated that several analogues of the natural product nostoclides, lacking the isopropyl group at carbon 4, exhibit moderate cytotoxicity against at least one of the cell lines tested (HL-60, HCT-8, MDA/MB-435 and SF295). In general, the presence of a bromine atom at the benzyl group linked at carbon 3 of the lactone ring results in decreased activity. The nature of the groups linked to the benzylidene ring influences the biological activities in this series of compounds. It 
appears that more polar groups like $\mathrm{OH}$ are associated with increased bioactivity. Further detailed investigation on the structure-activity relationship should consider the substitution pattern on both aromatic rings as a means to lead to the discovery of a more potent and selective cytotoxic compound.

\section{Experimental}

\section{General}

All reactions were carried out under a protective atmosphere of dry nitrogen. Dichloromethane and diisopropylethylamine (DIPEA) were purified as described by Perrin and Armarego [37]. Infrared spectra were recorded on a Perkin Elmer Paragon 1000 FTIR spectrophotometer, using potassium bromide $(1 \% \mathrm{w} / \mathrm{w})$ disks, scanning from 625 to $4000 \mathrm{~cm}^{-1}$. Flash column chromatography was performed using Crosfield Sorbil C60 (32-63 $\mu \mathrm{m})$. Analytical thin layer chromatography analysis was conducted on aluminum packed precoated silica gel plates. Melting points were determined on an electrothermal digital apparatus model MQAPF-301 (Microquimica, Brazil), without correction. The ${ }^{1} \mathrm{H}$ - and ${ }^{13} \mathrm{C}$-NMR spectra were recorded on a Bruker AVANCE DRX 400 spectrometer at 400 and $100 \mathrm{MHz}$, respectively, using $\mathrm{CDCl}_{3}$ as solvent (unless otherwise stated) and TMS as internal standard. Mass spectra were obtained on Shimadzu GCMS-QP5050A instrument by direct injection using the following temperature program: $40^{\circ} \mathrm{C} / \mathrm{min}$ until temperature reaches $60{ }^{\circ} \mathrm{C}$; then $80{ }^{\circ} \mathrm{C} / \mathrm{min}$ until temperature reaches $300{ }^{\circ} \mathrm{C}$; detector temp: $280{ }^{\circ} \mathrm{C}$. Commercially available tert-butyldimethylsilyltrifluoromethanesulfonate (TBDMSOTf), 8-diazabicyclo[5.4.0]-undec-7-ene (DBU), and aldehydes were purchased from Aldrich (Milwaukee, WI, USA) and utilized without further purification. The preparation of the corresponding silyl enol ethers from 2-hydroxybenzaldehyde, 3-hydroxybenzaldehyde and 4-hydroxybenzaldehyde was carried out utilizing the methodology described by Pettit and co-workers [38]. The lactones 3-benzylfuran-2(5H)-one (2a) and 3bromobenzylfuran-2(5H)-one (2b) were synthesized as described in the literature [39].

Synthesis of 5(Z)-3-benzyl-5-(1,3-dioxalenebenzylidene)-furan-2(5H)-one (5)

To a two-neck round bottom flask, under nitrogen atmosphere, were added 3-benzyl-5H-furan-2one (3) (106 mg, $0.61 \mathrm{mmol}$ ), anhydrous dichloromethane (3 mL), TBDMSOTf (170 $\mu \mathrm{L}, 0.74 \mathrm{mmol}$ ), diisopropylethyl amine (310 $\mu \mathrm{L}, 1.8 \mathrm{mmol})$ and piperonal (180 mg; $1.2 \mathrm{mmol})$. The resulting mixture was stirred at room temperature for 1 hour. After adding DBU (180 $\mu \mathrm{L}, 1.22 \mathrm{mmol})$, the reaction mixture was refluxed for an additional 3 hours and dichloromethane $(70 \mathrm{~mL})$ was added. The resulting organic layer was washed with $3 \mathrm{M} \mathrm{HCl}$ aqueous solution $(2 \times 25 \mathrm{~mL})$ and brine $(25 \mathrm{~mL})$. After separation, the organic layer was dried over $\mathrm{MgSO}_{4}$, filtered, and concentrated under reduced pressure. The resulting material was purified by column chromatography on silica gel eluted with hexanediethyl ether (6:1). Fractions containing the desired product were combined and the solvent was removed under reduced pressure. The resulting solid was recrystallized from a mixture of hexanedichloromethane $(5: 1 \mathrm{v} / \mathrm{v})$. Compound 5 was obtained as pale yellow crystals in 83\% yield (155 mg; $0.51 \mathrm{mmol}$ ). TLC: $\mathrm{R}_{\mathrm{f}}=0.20$ (hexane-diethyl ether $\left.6: 1 \mathrm{v} / \mathrm{v}\right)$; mp $181.1-181.8{ }^{\circ} \mathrm{C}$; IR $\left(\mathrm{cm}^{-1}\right) \bar{v}_{\max }: 3108$, 3055, 3025, 2892, 1736, 1654, 1600, 1489, 1446, 1379, 1341, 1262, 1036, 935; ${ }^{1} \mathrm{H}-\mathrm{NMR} \delta$ : 3.71 (s, 
2H, H7), 5.78 (s, 1H, H6), 5.98 (s, 2H, -O-CH $-\mathrm{O}-$ ), 6.79 (d, 1H, J = $8.2 \mathrm{~Hz}, \mathrm{H3}$ ”), 6.91 (s, 1H, H4), 7.10 (dd, $1 \mathrm{H}, J=8.2 \mathrm{~Hz}$ and $J=1.3 \mathrm{~Hz}, \mathrm{H} 2$ ”), 7.25-7.36 (m, 5H, Ph), 7.42 (d, $1 \mathrm{H}, J=1.3 \mathrm{~Hz}$, H6”); ${ }^{13} \mathrm{C}-\mathrm{NMR} \delta$ : 31.68 (C7), 101.47 (-O-CH $\left.2-\mathrm{O}-\right), 108.56$ (C3”), 109.94 (C6”), 112.66 (C6), 125.74 (C2”), 126.92 (C4'), 127.51 (C1”), 128.84, (C3’/C5'), 128.93 (C2'/C6'), 131.56 (C3), 137.36 (C1'), 139.60 (C4), 146.24 (C5), 148.42/148.26 (C4”/C5”), 170.42 (C2); MS, m/z (\%): 306, $\mathrm{C}_{19} \mathrm{H}_{14} \mathrm{O}_{4},\left[\mathrm{M}^{+}\right.$], (100), 261 (4), 231 (8), 203 (8), 162 (32), 153 (7), 134 (34), 115 (22), 104 (17), 101 (18), 91 (13),77 (9), 76 (39), 65 (8), 51 (11).

Compounds 6-11 were prepared using a procedure similar to that described for the synthesis of compound 5, and yields are presented in Scheme 1. Lactones 6, 9, 10 and 11 were obtained using lactone $\mathbf{2 b}$ as starting material. Structures of the synthesized compounds were supported by the following spectroscopic and analytical data.

5(Z)-3(4-Bromobenzyl)-5-(1,3-dioxalenebenzylidene)furan-2(5H)-one (6). Purified by silica gel column chromatography with hexane-dichloromethane $1: 1 \mathrm{v} / \mathrm{v}$ as eluent ; yellow solid; yield, 40\%; TLC: $\mathrm{R}_{\mathrm{f}}=0.15$ (hexane-dichloromethane $1: 2 \mathrm{v} / \mathrm{v}$ ); $\mathrm{mp} 175.6-176.0{ }^{\circ} \mathrm{C}$; IR $\left(\mathrm{cm}^{-1}\right) \bar{v}_{\max }: 3102,2891$, 1729, 1650, 1599, 1499, 1488, 1267, 1045, 1034, 940; ${ }^{1} \mathrm{H}-\mathrm{NMR} \delta$ : 3.66 (s, 2H, H7), 5.81 (s, 1H, H6), 5.99 (s, 2H, -O-CH2-O-), 6.80 (d, 1H, $J=8.2 \mathrm{~Hz}, \mathrm{H} 5$ ') ') 6.93 (s, 1H, H4), 7.11 (dd, $1 \mathrm{H}, J=8.2 \mathrm{~Hz}$ and $J=1.6 \mathrm{~Hz}, \mathrm{H6}$ '’), 7.13 (d, 2H, $J=8.3 \mathrm{~Hz}, \mathrm{H} 2^{\prime} / \mathrm{H6}$ '), 7.42 (d, 1H, $J=1.6 \mathrm{~Hz}, \mathrm{H} 2$ ' '), 7.46 (d, 2H, $J=$ 8.3 Hz, H3'/H5’); ${ }^{13} \mathrm{C}-\mathrm{NMR} \delta$ : 31.11 (C7), 101.50 (-O-CH$\left.-\mathrm{O}-\right), 108.58$ (C5’'), 109.98 (C2’’), 113.07 (C6), 120.87 (C4’), 125.87 (C6’'), 127.39 (C1’'), 130.63 (C2’/C6’), 130.75 (C3), 131.95 (C3’/C5'), 136.33 (C1'), 139.69 (C4), 146.06 (C5), 148.28 (C3’’), 148.53 (C4’’), 170.21 (C2); MS, m/z (\%) 384 $\left(\mathrm{C}_{19} \mathrm{H}_{13} \mathrm{BrO}_{4}\left[\mathrm{M}^{+}\right.\right.$], 83$), 386$ ([M+2], 88), 339 (6), 304 (8), 276 (7), 259 (11), 219 (11), 189 (17), 169 (15), 162 (70), 134 (78), 115 (47), 104 (39), 89 (29), 76 (100), 63 (26), 50 (55).

5(E)-3-Benzyl-5-(2,4,6-trimethoxybenzylidene)furan-2(5H)-one (7). Purified by silica gel column chromatography using hexane-ethyl acetate $4: 1 \mathrm{v} / \mathrm{v}$ as eluent; yellow solid; yield, 86\%; TLC: $\mathrm{R}_{\mathrm{f}}=0.29$ (hexane-ethyl acetate 4:1 v/v); mp 107.9-109.0 ${ }^{\circ} \mathrm{C}$; IR $\left(\mathrm{cm}^{-1}\right) \bar{v}_{\text {max }}$ : 3001, 2938, 2840, 1747, 1602, 1583, 1495, 1469, 1455, 1229, 1119, 953, 814, 701; 'H-NMR $\delta$ : 3.68 (s, 2H, H7), 3.72 (s, 6H, 2”/6”$\mathrm{OCH}_{3}$ ), 3.82 (s, 3H, 4”-OCH 3 ), 6.10 (s, 2H, H-3”/H-5”), 6.54 (s, 1H, H6), 7.05 (s, 1H, H4), 7.22-7.33 (m, 5H, Ph); ${ }^{13} \mathrm{C}-\mathrm{NMR} \delta$ : 31.82 (C7), 55.42 (4”-OCH $), 55.57$ (2”/6”-OCH $), 90.74$ (C3”/C5”), 103.82 (C1”), 105.65 (C6), 126.72 (C4’), 128.67 (C3’/C5'), 128.96 (C2'/C6'), 132.92 (C3), 137.77 (C1'), 137.85 (C4), 148.70 (C5), 158.71 (C2”/C6”), 161.89 (C4”), 170.25 (C2); MS, m/z (\%): $352\left(\mathrm{C}_{21} \mathrm{H}_{20} \mathrm{O}_{5}\right.$ [M $\mathrm{M}^{+}$], 100), 281 (7), 208 (8), 193 (11), 181 (15), 166 (27), 138 (23), 115 (16), 91 (19), 77 (10), 76 (5), 69 (12), 65 (9), 51 (6).

5(Z)-3-Benzyl-5-(4-bromobenzylidene)furan-2(5H)-one (8). Purified by silica gel column chromatography using hexane-dichloromethane 2:1 v/v as eluent; white solid; yield, 75\%; TLC: $\mathrm{R}_{\mathrm{f}}=$ 0.20 (hexane-dichloromethane 2:1 v/v); mp 162.4-163.6 ${ }^{\circ} \mathrm{C}$; IR $\left(\mathrm{cm}^{-1}\right) \bar{v}_{\text {max }}: 3100,3028,2929,2852,1763$, 1649, 1608, 1577, 1033, 856, 696; ${ }^{1} \mathrm{H}-\mathrm{NMR} \delta$ : 3.72 (s, 2H, H7), 5.79 (s, 1H, H6), 6.93 (s, 1H, H4), 7.257.37 (m, 5H, Ph), 7.49 (d, 2H, $J=8.6 \mathrm{~Hz}, 2 \mathrm{H}, \mathrm{H3}$ ”/H5”), 7.59 (d, 2H, $J=8.6 \mathrm{~Hz}, 2 \mathrm{H}, \mathrm{H} 2 ” / \mathrm{H} 6$ ”); ${ }^{13} \mathrm{C}-$ NMR $\delta$ : 31.77 (C7), 111.27 (C6), 123.19 (C4”), 127.05 (C4’), 128.92 (C3’/C5’), 128.95 (C2’/C6’), 131.77 
(C2”/C6”), 132.03 (C3”/C5”), 132.08 (C1”), 133.09 (C3), 137.05 (C1'), 139.48 (C4), 147.85 (C5), 170.10 (C2); MS, m/z (\%): $340\left(\mathrm{C}_{18} \mathrm{H}_{13} \mathrm{BrO}_{2}\left[\mathrm{M}^{+}\right.\right.$], 49$), 342$ ([M+2], 46), 243 (19), 215 (35), 202 (15), 115 (47), 89 (100), 77 (8), 63 (34), 51 (13).

5(Z)-3(4-Bromobenzyl)-5-(benzylidene)furan-2(5H)-one (9). Purified by silica gel column chromatography eluting with hexane-dichloromethane 2:1 v/v; white solid; yield, 98\%; TLC $\mathrm{R}_{\mathrm{f}}=0.20$ (hexane-dichloromethane 2:1 v/v); mp 127.3-127.9 ${ }^{\circ} \mathrm{C}$; IR $\left(\mathrm{cm}^{-1}\right) \bar{v}_{\text {max }}$ : 3102, 3058, 3022, 1764, 1649, 1609, 1486, 1362, 1026, 930, 759; ${ }^{1} \mathrm{H}-\mathrm{NMR} \delta$ : 3.68 (s, 2H, H7), 5.89 (s, 1H, H6), 6.96 (t, 1H, $J=1.4$ $\mathrm{Hz}, \mathrm{H} 4), 7.14$ (d, 2H, $J=8.4 \mathrm{~Hz}, \mathrm{H} 2^{\prime} / \mathrm{H} 6$ ') 7.30 (t, 1H, $J=7.2, \mathrm{H} 4^{\prime \prime}$ ), 7.39 (t, 2H, $J=7.2 \mathrm{~Hz}$ and $J=$ $7.2 \mathrm{~Hz}, \mathrm{H} 3$ '’/H5' '), 7.46 (d, 2H, $J=8.4 \mathrm{~Hz}, \mathrm{H} 3$ '/H5'), 7.73 (d, 2H, $J=7.2 \mathrm{~Hz}, \mathrm{H} 2$ '’/H6' '); ${ }^{13} \mathrm{C}-\mathrm{NMR}$

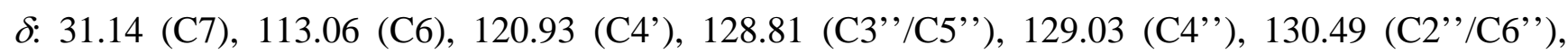
130.62 (C2'/C6'), 131.75 (C3), 131.97 (C3’/C5'), 133.02 (C1’’), 136.16 (C1'), 139.74 (C4), 147.29 (C5), 170.18 (C2), MS, m/z (\%) 340 ( $\mathrm{C}_{18} \mathrm{H}_{13} \mathrm{BrO}_{2}\left[\mathrm{M}^{+}\right.$], 41$), 342$ ([M+2], 38), 322 (3), 295 (5), 261 (9), 243 (23), 233 (13), 217 (16), 216 (30), 215 (41), 202 (18), 189 (3), 171 (8), 156 (3), 143 (13), 115 (56), 101 (13), 91 (15), 90 (100), 77 (9), 63 (27), 51 (15).

5(Z)-3(4-Bromobenzyl)-5-(3-methylbenzylidene)furan-2(5H)-one (10). Purified by silica gel column chromatography with hexane-dichloromethane 2:1 v/v as eluent; white solid; yield, $59 \% ; \mathrm{R}_{\mathrm{f}}=0.20$ (hexane-dichloromethane 2:1 v/v); mp 111.2 - $111.9^{\circ} \mathrm{C}$; IR $\left(\mathrm{cm}^{-1}\right) \bar{v}_{\max }: 3108,1747,1648,1488$, 1419, 1341, 1072, 1034, 914, 899, 793; ${ }^{1} \mathrm{H}-\mathrm{NMR} \delta: 2.37$ (s, 3H, -C $\underline{\mathrm{H}}_{3}$ ), 3.68 (brs, 2H, H7), 5.86 (s, 1H, H6), 6.95 (t, 1H, $J=1.3 \mathrm{~Hz}, \mathrm{H} 4), 7,12$ (d, 1H, $J=7.6 \mathrm{~Hz}, \mathrm{H} 4$ ' ') 7.14 (d, 2H, $J=8.3 \mathrm{~Hz}, \mathrm{H2}$ '/H6'), 7.26 (t, 1H, $J=7.6 \mathrm{~Hz}, \mathrm{H} 5$ '’), 7.47 (d, 2H, $J=8.3 \mathrm{~Hz}, \mathrm{H3}$ '/H5'), 7.54 (d, 1H, $J=7.6$ Hz, H6' '), 7.55 (s, 1H, H2' '); ${ }^{13} \mathrm{C}-\mathrm{NMR} \delta$ : $21.41\left(\mathrm{CH}_{3}\right), 31.13$ (C7), 113.32 (C6), 120.92 (C4'), 127.77 (C6'”), 128.71 (C5’'), 129.97 (C4’'), 130.65 (C2'/C6'), 131.01 (C2'’), 131.56 (C3), 131.97 (C3'/C5'), 132.94 (C1'’), 136.22 (C1'), 138.48 (C3’'), 139.82 (C4), 147.16 (C5), 170.30 (C2); MS, m/z (\%): $354\left(\mathrm{C}_{19} \mathrm{H}_{15} \mathrm{BrO}_{2}\right.$ [M+'], 93), 356 ([M+2], 95), 336 (7), 311 (9), 275 (12), 257 (35)247 (21), 230 (44), 229 (45), 215 (35), 204 (18), 169 (16), 143 (26), 132 (50), 115 (89), 104 (69), 89 (47), 78 (100), 63 (34), 51 (31).

5(Z)-3(4-Bromobenzyl)-5-(3-nitrobenzylidene)furan-2(5H)-one (11). Purified by silica gel column chromatography eluting with hexane-dichloromethane 1:2 v/v; pale yellow solid; yield, 31\%; TLC: $\mathrm{R}_{\mathrm{f}}$ $=0.44$ (hexane-dichloromethane $1: 2 \mathrm{v} / \mathrm{v})$; $\mathrm{mp} 122.8-123.9{ }^{\circ} \mathrm{C}$; IR $\left(\mathrm{cm}^{-1}\right) \bar{v}_{\max }: 3097,2936,2892$, 2838, 1754, 1653, 1609, 1570, 1530, 1352, 1034, 907; ${ }^{1} \mathrm{H}-\mathrm{NMR} \delta$ : 3.71 (s, 1H, H7), 5.93 (s, 1H, H6), 7.01 (s, 1H, H4), 7.15 (d, 2H, $J=8.3$ Hz, H2'/H6'), 7.48 (d, 2H, $J=8.3$ Hz, H3'/H5'), 7.56 (t, 1H, $J=$ $8.1 \mathrm{~Hz}, \mathrm{H} 5$ '’), 8.14 (t, 2H, $J=8.1 \mathrm{~Hz}, \mathrm{H} 4$ '’/H6'”), 8.42 (s, 1H, H2'’); ${ }^{13} \mathrm{C}-\mathrm{NMR} \delta: 31.26$ (C7), 109.82 (C6), 121.16 (C4'), 123.17 (C4’'), 124.74 (C2’'), 129.83 (C5’'), 130.65 (C2'/C6’), 132.10 (C3'/ C5'), 133.65 (C1'), 134.65 (C1’’), 135.62 (C6’), 135.67 (C3), 139.22 (C4), 148.59 (C3’”), 148.98 (C5), 169.32 (C2), MS, m/z (\%): $485\left(\mathrm{C}_{18} \mathrm{H}_{12} \mathrm{BrNO}_{4}\right.$ [M ${ }^{+}$], 45), 387 ([M+2], 45), 370 (43), 368 (44), 350 (6), 306 (11), 288 (7), 278 (13), 259 (7), 231 (15), 216 (16), 202 (34), 193 (9), 169 (15), 143 (17), 115 (99), 89 (100), 63 (74), 51 (19).

Synthesis of (Z)-3-benzyl-5-(4-hydroxybenzylideno)furan-2(5H)-one (12). A $25 \mathrm{~mL}$ round bottom flask, under nitrogen atmosphere, was charged with 4-tert-butyldimethylsilyloxybenzaldehyde (0.243 
g, $1.03 \mathrm{mmol}$ ), 3-benzylfuran-2(5H)-one (2a, $0.150 \mathrm{~g}, 0.86 \mathrm{mmol})$, anhydrous dichloromethane (4 $\mathrm{mL}$ ), TBDMSOTf (250 $\mu \mathrm{L}, 1.03 \mathrm{mmol}$ ) and diisopropylethylamine (450 $\mu \mathrm{L}, 2.58 \mathrm{mmol})$. The resulting mixture was stirred at room temperature for $1 \mathrm{~h}$ and after this time DBU (260 $\mu \mathrm{L}, 1.72 \mathrm{mmol})$ was added. The reaction mixture was then refluxed for a further 3 hours before addition of dichloromethane $(70 \mathrm{~mL})$. The resulting organic layer was washed with $3 \mathrm{M}$ aqueous $\mathrm{HCl}$ solution $(2 \mathrm{x}$ $25 \mathrm{~mL}$ ) and brine (25 mL). After separation, the organic layer was dried over $\mathrm{MgSO}_{4}$, filtered, and concentrated under reduced pressure to afford a pale yellow oil. To this oil, placed in a plastic flask, was added $3 \mathrm{~mL}$ of a MeCN/HF (1:1 v/v) solution. The resulting mixture was stirred at room temperature for 3 hours and then transferred to a separatory funnel containing ethyl acetate $(80 \mathrm{~mL})$. The layers were separated and the organic layer was washed with saturated sodium bicarbonate solution $(3 \times 25 \mathrm{~mL})$. The aqueous extracts were combined and the resulting aqueous layer was extracted with ethyl acetate $\left(2 \times 50 \mathrm{~mL}\right.$ ). The combined organic extracts were dried over $\mathrm{MgSO}_{4}$, filtered, and concentrated under reduced pressure. The resulting crude product material was purified by silica gel column chromatography eluted with hexane-ethyl acetate $(2: 1 \mathrm{v} / \mathrm{v})$ to afford compound (12) in 91\% yield (218 mg, $0.78 \mathrm{mmol}$ ). Yellow solid; TLC: $\mathrm{R}_{\mathrm{f}}=0.22$ (hexane-ethyl acetate 2:1 v/v); mp 198.2-199.3 ${ }^{\circ} \mathrm{C}$; IR $\left(\mathrm{cm}^{-1}\right) \bar{v}_{\text {max }}$ : 3364 (broad), 3286, 2928, 1731, 1603, 1283, 1053, 832, 700; ${ }^{1} \mathrm{H}-$ NMR $\left(\mathrm{CDCl}_{3}\right.$ containing drops of DMSO- $\left.\mathrm{d}_{6}\right) \delta: 3.70$ (s, 2H, H7), 5.84 (s, 1H, H6), 6.85 (d, $2 \mathrm{H}, J=8.7$ Hz, H3”/H5”), 6.98 (s, 1H, H4), 7.24-7.35 (m, 5H, Ph), 7.38 (s, 1H, OH), 7.60 (d, 2H, J=8.7 Hz, H2”/H-6”); ${ }^{13} \mathrm{C}-\mathrm{NMR}\left(\mathrm{CDCl}_{3}\right.$ containing drops of DMSO-d $\left.d_{6}\right) \delta$ : 31.53 (C7), 113.33 (C6), 116.10 (C3”/C5”), 124.64 (C1”), 126.79 (C4'), 128.75 (C3’/C5’), 128.83 (C2’/C6’), 130.37 (C3), 132.28 (C2”/C6”), 137.51 (C1'), 139.89 (C4), 145.47 (C5), 158.58 (C4”), 170.76 (C2); MS, m/z (\%): $278\left(\mathrm{C}_{18} \mathrm{H}_{14} \mathrm{O}_{3},\left[\mathrm{M}^{+}\right.\right.$], 100), 260 (7), 233 (15), 215 (9), 202 (5), 172 (5), 144 (13),134 (30), 115 (30), 106 (34), 91 (17), 78 (26), 77 (32), 65 (13), 51 (25).

Compounds 13-14 were prepared using the same experimental procedure described for the synthesis of compound 12, and yields are presented in Scheme 1. Structures of the synthesized compounds were supported by the following spectroscopic and analytical data.

5(Z)-3-Benzyl-5-(3-hydroxybenzylidene)furan-2(5H)-one (13). Purified by silica gel column chromatography eluting with hexane-ethyl acetate $2: 1 \mathrm{v} / \mathrm{v}$; yellow solid; yield, 74\%; TLC: $\mathrm{R}_{\mathrm{f}}=0.35$ (hexane-ethyl acetate, 2:1 v/v); mp 141.2-141.6 ${ }^{\circ} \mathrm{C}$; IR $\left(\mathrm{cm}^{-1}\right) \bar{v}_{\text {max }}: 3373$ (broad band), 3097, 3028, 1737, 1650, 1590, 1453, 1054, 937, 885, 766, 697; ${ }^{1} \mathrm{H}-\mathrm{NMR} \delta 3.72$ (brs, 2H, H7), 5.82 (s, 1H, H6), 6.82 (ddd, $1 \mathrm{H}, J=7.8 \mathrm{~Hz}, J=2.5$ and $J=1.0 \mathrm{~Hz}, \mathrm{H} 4$ ”), 6.93 (t, 1H, $J=1.4 \mathrm{~Hz}, \mathrm{H} 4$ ), 7.16 (bd, $1 \mathrm{H}, J=$ $7.8 \mathrm{~Hz}, \mathrm{H} 2$ ”), 7.17 (t, 1H, $J=7.8 \mathrm{~Hz}, \mathrm{H} 3$ ”), 7.20-7.37 (m, 6H, OH and Ph), 7.39 (dd, $J=2.5$ and $J=$ 1.4, H-6”); ${ }^{13}$ C-NMR $\delta$ : 31.66 (C7), 112.58 (C6), 116.39 (C6”), 116.54 (C4”), 123.30 (C-2”), 126.97 (C4'), 128.57 (C3’/C5') , 128.92 (C2’/C6'), 129.90 (C3”), 132.61 (C3), 134.37 (C1”), 137.07 (C1'), 139.75 (C4), 147.54 (C5), 156.00 (C5”), 170.60 (C2); MS, m/z (\%): $278\left(\mathrm{C}_{18} \mathrm{H}_{14} \mathrm{O}_{3}, \mathrm{M}^{+}\right.$], 100), 260 (8), 233 (23), 215 (15), 202 (7), 172 (6), 144 (20), 131 (13), 115 (42), 105 (30), 91 (42), 78 (31), 77 (43), 65 (16), 51 (36).

5(Z)-3-Benzyl-5-(2-hydroxybenzylidene)furan-2(5H)-one (14). Purified by silica gel column chromatography using hexane-ethyl acetate $3: 1 \mathrm{v} / \mathrm{v}$ as eluent; yellow solid; yield, 78 \%; TLC: Rf = 
0.15 (hexane-ethyl acetate, 3:1 v/v); mp, 185.9-187.1 ${ }^{\circ} \mathrm{C}$; IR $\left(\mathrm{cm}^{-1}\right) \bar{v}_{\text {max }}$ : 3341 (broad band), 1721, 1598, 1581, 1495, 1255, 1053, 940, 851, 758; ${ }^{1} \mathrm{H}-\mathrm{NMR} \delta$ : 3.73 (s, 2H, H7), 5.56 (s, 1H, OH), 6.31 (s, 1H, H6), 6.77 (d, 1H, $J=8.0 \mathrm{~Hz}, \mathrm{H3}$ ), 6,96 (dd, 1H, $J=8.0 \mathrm{~Hz}$ and $J=7.6 \mathrm{~Hz}, \mathrm{H} 5$ ”), 6.99 (s, 1H, H4), 7.18 (ddd, $1 \mathrm{H}, J=8.0 \mathrm{~Hz}, J=7.6 \mathrm{~Hz}$ and $J=1.2 \mathrm{~Hz}, \mathrm{H} 4$ ”), 7.25-7.36 (m, 5H, Ph), 7.99 (dd, $J=8.0$ and $J=1.2$, H6”); ${ }^{13} \mathrm{C}-\mathrm{NMR} \delta$ : 31.70 (C7), 107.00 (C6), 115.88 (C3”), 120.43 (C1”), 121.45 (C5”), 126.96 (C4'), 128.87 (C3’/C5'), 128.94 (C2'/C6’), 130.49 (C4”), 131.95 (C6”), 132.03 (C3), 137.22 (C1'), 139.97 (C4), 146.85 (C5), 153.85 (C2”), 170.21; MS, m/z (\%): $278\left(\mathrm{C}_{18} \mathrm{H}_{14} \mathrm{O}_{3},\left[\mathrm{M}^{+}\right.\right.$], 99$), 260$ (5), 233 (19), 215 (8), 202 (10), 187 (79), 172 (11), 159 (19), 144 (17), 131 (33), 115 (94), 105 (26), 91 (53), 78 (100), 77 (82), 65 (34), 51 (66).

\section{Biological activity assays}

The cytotoxicity of compounds 5-14 was tested against HL-60 (human leukemia), HCT-8 (human colon), SF-295 (human central nervous system) and MDA-MB 435 (human breast cancer) cell lines obtained from the National Cancer Institute, Bethesda, MD, USA. Cells were cultured in RPMI-1640 medium supplemented with $10 \%$ fetal calf serum, $2 \mathrm{mM}$ glutamine, $100 \mu \mathrm{g} / \mathrm{mL}$ streptomycin and 100 $\mathrm{U} / \mathrm{mL}$ penicillin and incubated at $37{ }^{\circ} \mathrm{C}$ under a $5 \% \mathrm{CO}_{2}$ atmosphere. For experiments, cells were seeded in 96-well plates $\left(0.7 \times 10^{5}\right.$ for adherents cells or $0.3 \times 10^{6}$ for suspended cells in $100 \mu \mathrm{L}$ medium). After $24 \mathrm{~h}$, the lactones 5-14 $(0.39-25 \mu \mathrm{g} / \mathrm{mL})$ dissolved in DMSO (5\%) were added to each well and incubated for 3 days $(72 \mathrm{~h})$. Control groups received the same amount of DMSO. Doxorubicin was used as positive control. Growth of tumoural cells was quantified by the ability of living cells to reduce the yellow dye 3-(4,5-dimethyl-2-thiazol)-2,5-diphenyl-2H-tetrazolium bromide (MMT) to a blue formazan product. At the end of $72 \mathrm{~h}$ incubation, the medium in each well was replaced by fresh medium (200 $\mu \mathrm{L}$ ) containing $0.5 \mathrm{mg} / \mathrm{mL}$ of MTT. Three hours later, the formazan product of MTT reduction was dissolved in DMSO $(150 \mu \mathrm{L})$, and absorbance was measured using a multiplate reader (Spectra Count, Packard, Ontario, Canada). The drug effect was quantified as percentage of the absorbance reduced dye at $550 \mathrm{~nm}$ in relation to control wells.

\section{Molecular Modeling and Statistical Analysis}

Minimum energy conformations and molecular properties were obtained by using AM1 semi empirical calculations [31] implemented in SPARTAN [40]. The $\mathrm{IC}_{50}$ values and their 95\% confidence intervals (CI 95\%) were obtained by nonlinear regression using the GRAPHAD software (Intuitive Software for Science, San Diego, CA, U.S.A.).

\section{Acknowledgements}

We are grateful to the following Brazilian agencies: Conselho Nacional de Desenvolvimento Científico e Tecnológico (CNPq) for research fellowships (LCAB, RRT, MER), Fundação de Amparo à Pesquisa de Minas Gerais (FAPEMIG), Coordenação de Aperfeiçoamento de Pessoal de Nível Superior (CAPES) e FINEP for financial support. We also would like to thank Dr. José Walkimar de Mesquita Carneiro (UFF) for invaluable assistance with computational chemistry. 


\section{References}

1. Brückner, R. The synthesis of $\gamma$-alkylidenebutenolides. Curr. Org. Chem. 2001, 5, 679-718.

2. Brückner, $\mathrm{R}$. The $\beta$-elimination route to setereodefined $\gamma$-alkylidenebutenolides. Chem. Commun. 2001, 141-152.

3. De Souza, M. V. N. The Furan-2(5H)-ones: Recent synthetic methodologies and its application in total synthesis of natural products. Mini-Rev. Org. Chem. 2005, 2, 546-564.

4. Negishi, E..; Kotora, M. Regio- and stereoselective synthesis of $\gamma$-alkylidenebutenolides and related compounds. Tetrahedron 1997, 53, 6707-6738.

5. Baer, H.; Holden, M.; Seegal, B.C. The nature of the antibacterial agent from anemone pulsatilla. J. Biol. Chem. 1946, 162, 65-68.

6. Shaw, E. A synthesis of protoanemonin. The tautomerism of acetylacrylic acid and penicillic acid. J. Am. Chem. Soc. 1946, 68, 2510-2513.

7. Grundmann, C.; Kober, E. An improved synthesis of protoanemonin. J. Am. Chem. Soc. 1955, 77, 2332-2333.

8. Fang, X.; Anderson, J.E.; Chang, C.; McLaughlin, J.L. Three new bioactive styryllactones from Goniothalamus giganteus (Annonaceae). Tetrahedron 1991, 47, 9751-9758.

9. Shing, T.K.M.; Tai, V.W.F.; Zhou, Z.H. Enantiospecific synthesis of (+)-goniofufurone, (+)-7epi-goniofufurone, $(+)$-goniobutenolide $\mathrm{A},(-)$-goniobutenolide $\mathrm{B},(+)$-goniopypyrone, $(+)$-altholactone, (+)-goniotriol, and (+)-7-acetylgoniotriol. J. Org. Chem. 1995, 60, 3121-3130.

10. Ko, S.Y.; Lerpiniere, J. Enantioselective synthesis of goniobutenolides A and B. Tetrahedron Lett. 1995, 36, 2101-2104.

11. Mukai, C.; Hirai,S.; Kim, I.J.; Kido, M.; Hanaoka, M. Studies on total synthesis of antitumor styryllactones: Stereoselective total synthesis of (+)-goniofufurane, (+)-goniobutenolide A, and () goniobutenolide B. Tetrahedron, 1996, 52, 6547-6560.

12. Surivet, J.P.; Vatèle, J.M. Concise total synthesis of (+)-goniofufurone and goniobutenolides A and B. Tetrahedron Lett. 1996, 37, 4373-4376.

13. Kuhnt, D.; Anke, T.; Besl, H.; Bross, M.; Herrmann, R.; Mocek, U.; Steffan, B.; Steglich, W. Antibiotics from basidiomycetes. XXXVII. New inhibitors of cholesterol biosynthesis from cultures of Xerula melanotricha Dorfelt. J. Antibiot. 1990, 43, 1413-1420.

14. Negishi, E.; Hu, Q.; Huang, Z.; Qian, M.; Wang, G. Palladium-catalyzed alkenylation by the Negishi coupling. Aldrichim. Acta 2005, 38, 71-87.

15. Flematti, G.R.; Ghisalberti, E.L.; Dixon, K.W.; Trengove, R.D. A compound from smoke that promotes seed germination. Science 2004, 305, 977.

16. Vaz, B.; Alvarez, R.; Brückner, R.; Lera, A.R. The Stille reaction in the synthesis of carotenoid butenolides: synthesis of 6'-epi-peridinin. Org. Lett. 2005, 7, 545-548.

17. Yang, X.; Shimizu, Y.; Steiner, J.R.; Clardy, J. Nostoclide I and II, extracellular metabolites from a symbiotic cyanobacterium, Nostoc sp., from the lichen Peltigera Canina. Tetrahedron Lett. 1993, 34, 761-764. 
18. Boukouvalas, J.; Maltais, F.; Lachance, N. Furanolate-based strategy for sequential 2,3,4-trisubstitution of butenolide : Total synthesis of nostoclides I and II. Tetrahedron Lett. 1994, 35, 7897-7900.

19. Bellina, F.; Rossi, R. Synthetic applications of 3,4-dihalo-2-(5H)-furanones: A formal total synthesis of nostoclides I and II. Synthesis 2002, 2729-2732.

20. Kar, A.; Gogoi, S.; Argade, N.P. Synthesis of naturally occurring bioactive butyrolactones: maculalactones A-C and nostoclide I. Tetrahedron 2005, 61, 5297-5302.

21. Barbosa, L.C.A.; Demuner, A.J.; Borges, E.E.L.; Mann, J. Synthesis and evaluation of the plant growth regulatory activity of 8-oxabicyclo[3.2.1] oct-6-en-3-one derivatives. J. Braz. Chem. Soc. 1997, 8, 19-27.

22. Barbosa, L.C.A.; Costa, A.V.; Piló-Veloso, D.; Lopes, J.L.C.; Terrones, M.G.H.; Diaz, B.K.; Blas, L.H. Phytogrowth-inhibitory lactones derivatives of Glaucolide B. Z.Naturforsch. 2004, 59c, 803-810.

23. Barbosa, L.C.A.; Maltha, C.R.A.; Demuner, A.J.; Ganen, F.A. Síntese de novas fitotoxinas derivadas do 8-oxabiciclo[3.2.1]oct-6-en-3-ona. Quim. Nova 2005, 28, 444-450.

24. Chaves, F.C.; Barbosa, L.C.A.; Demuner, A.J.; Silva, A.A. New Helminthosporal analogues with plant-growth regulatory properties synthesized via oxyallyl cation. Z. Naturforsch. 2006, 61b, 1287-1294.

25. Barbosa, L.C.A.; Alvarenga, E.S.; Demuner, A.J.; Virtuoso, L.S.; Silva, A.A. Synthesis of new phytogrowth-inhibitory substituted aryl-p-benzoquiones. Chem. Biodiv. 2006, 3, 553-567.

26. Casiraghi, G.; Zanardi, F.; Appendino, G.; Rasu, G. The vinylogous aldol reaction: a valuable, yet understated carbon-carbon bond-forming maneuver. Chem. Rev. 2000, 100, 1929-1972.

27. Boukouvalas, J.; Lachance, N.; Ouellete, M.; Trudeau, M. Facile access to 4-aryl-2(5H)-furanones by Suzuki cross coupling: efficient synthesis of rubrolides C and E. Tetrahedron Lett. 1998, 39, 7665-7668.

28. Bellina, F.; Anselmi, C.; Viel, S.; Mannina, L.; Rossi, R. Selective synthesis of (Z)-4-aryl-5-[1(aryl)methylidene]-3-bromo-2(5H)-furanones. Tetrahedron 2001, 57, 9997-10007.

29. Bellina, F.; Anselmi, C.; Rossi, R. Total synthesis of rubrolide M and some of its unnatural congeners. Tetrahedron Lett. 2002, 43, 2023-2027.

30. Greene, T.W.; Wuts, P.G.M.; Protective Groups in Organic Synthesis ( $3^{\text {rd }}$ edn). John Wiley \& Sons, Inc., New York, 1990.

31. Dewar, M.J.S.; Zoebisch, E.G.; Healy, E.F.; Stewart, J.J.P. AM1: A new general purpose quantum chemical molecular model. J. Am. Chem. Soc. 1985, 107, 3902-3909.

32. Teixeira, R.R.; Barbosa, L.C.A.; Santana, J.O.; Veloso, D.P.; Ellena, J.; Doriguetto, A.C.; Drew, M.G.B.; Ismail, F.M.D. Synthesis and structural characterization of two nostoclides analogues. $J$. Mol. Struct. 2007, 837, 197-205.

33. Skehan, P.; Storeng, R.; Scudiero, D.A.; Monks, A.; McMahon, J.; Vistica, D.; Warren, J.T.; Bodesch, H.; Kenney, S.; Boyd, M.R. New colorimetric cytotoxicity assay for anticancer-drug screening. J. Natl. Cancer Inst. 1990, 82, 1107-1112.

34. Mosman, T. Rapid colorimetric assay for cellular growth and survival: Application to proliferation and cytotoxicity assays. J. Immunol. Meth. 1983, 65, 55-63. 
35. Alley, M.C.; Scudiero, D.A.; Monks, A.; Hursey, M.L.; Czerwinski, M.J.; Fine, D.L.; Abbott, B.J.; Mayo, J.G.; Shoemaker, R.H.; Boyd, M.R. Feasibility of drug screening with panels of human tumor cell lines using a microculture tetrazolium assay. Cancer Res. 1988, 48, 589-601.

36. Berridge, M.V.; Tan, A.S.; McCoy, K.D.; Wang, R. The biochemical and cellular basis of cell proliferation assays that use tetrazolium salts. Biochemica 1996, 4, 15-20.

37. Perrin, D.D.; Armarego, W.L.F.; Purification of Laboratory Chemicals ( $3^{\text {rd }}$ edn); Pergamon: Oxford, 1988.

38. Pettit, G.R.; Grealish, M.P.; Jung, K.; Harmel, E.; Pettit, R.K.; Chaput, J.C.; Schmidt, J.M. Antineoplastic agents.465.Strucutrual modificaction of resveratrol: sodium reverastatin phosphate J. Med. Chem. 2002, 45, 2534-2542.

39. Barbosa, L.C.A.; Demuner, A.J.; Alvarenga, E.S.; Oliveira, A.; Diaz, B.K.; Hennsen, B.L. Phytogrowth, and photosynthesis-inhibiting properties of nostoclides analogues. Pest Manag. Sci. 2006, 62, 214-222.

40. PC Spartan Pro, Wavefunction, Inc., 1999.

Sample availability: Small amounts of compounds 5-14 are available from the corresponding author.

(C) 2007 by MDPI (http://www.mdpi.org). Reproduction is permitted for noncommercial purposes. 